\title{
Drzewa martwe i mikrosiedliska nadrzewne w ocenie stanu i planowaniu ochrony leśnych siedlisk przyrodniczych
}

\author{
Pawee Pawlaczyk
}

\begin{abstract}
PAWlACZyK, P. 2020. Deadwood and tree microhabitats in conservation status assessment and management planning of natural habitats in forest. Fragmenta Floristica et Geobotanica Polonica 27(1): 17-32. Kraków. e-ISSN 2449-8890, ISSN 1640-629X.
\end{abstract}

\begin{abstract}
The objective of the EU Habitat Directive and the Natura 2000 site program is to conserve biological diversity through conservation of natural habitats. In line with this objective, conservation of the structural diversity of habitats, including deadwood and tree microhabitats, is crucial. In all EU countries the volume or number of dead trees and the number of "habitat trees" is taken into account in assessing habitat conservation status, although the details and threshold values vary between countries. A lack of those features, and too-low thresholds for them, may lead to ineffective implementation of a Natura 2000; this means that even a forest that has a favourable conservation status may not maintain or restore the biodiversity of its habitats. In the Polish system of natural habitats monitoring, the total volume of deadwood and coarse woody debris is surveyed. In some types of forest habitats the number of trees providing microhabitats is also recorded. The objective of increasing deadwood and habitat tree resources is taken into account in drafting Natura 2000 site management plans, but measures consisting only of leaving deadwood and habitat trees seem insufficient. The opportunities offered by occasional disturbances should be seized, and some trees should be allowed to age and die so that they provide particular microhabitat structures.
\end{abstract}

KEY WORDS: conservation management, conservation status, deadwood, forest natural habitats, Natura 2000, tree microhabitats

P. Pawlaczyk, Klub Przyrodników, ul. 1 Maja 22, 66-200 Świebodzin, Polska;

e-mail: pawel.pawlaczyk@kp.org.pl

\section{WSTEP}

Rozkładające się drewno ma w lesie duże znaczenie dla dynamiki ekosystemu oraz dla leśnej różnorodności biologicznej. Nie ma dziś wątpliwości co do tej tezy, a liczba publikacji naukowych analizujących różne aspekty tego zagadnienia sięgnęła kilkudziesięciu tysięcy. Współcześnie coraz więcej wysiłku badawczego poświęcanego jest także różnym innym elementom strukturalnym związanym z drzewami, określanym jako mikrosiedliska nadrzewne, które zwykle powstają w wyniku uszkodzeń żywych drzew, ale mogą występować również na drzewach martwych. Wiele gatunków, będących w warunkach naturalnych komponentami ekosystemu leśnego, zależnych jest od takich mikrosiedlisk. Utrzymanie lub odtworzenie zróżnicowania strukturalnego ekosystemu, czego elementem są właśnie drzewa martwe i drzewa ze specyficznymi mikrosiedliskami, należy do pryncypiów 
zarządzania ekosystemami, zarówno w obszarach chronionych, jak i w ramach integracji celów ochronnych z gospodarką leśną (por. GUTOWSKI i in. 2004; LINDENMAYER i in. 2006; Stokland i in. 2012; Kraus \& Krumm 2013; Pawlaczyk 2016; BaČE i in. 2019 i cytowana tam literatura).

Znaczącym nurtem współczesnej ochrony przyrody jest dążenie do tzw. „właściwego stanu ochrony" siedlisk przyrodniczych, rozumianego jako trwały stan istnienia ekosystemu ze wszystkimi typowymi dla niego elementami struktury i procesami. W stosunku do niektórych typów ekosystemów, uznanych za przedmiot zainteresowania Wspólnoty Europejskiej, cel taki stawia w swoim artykule 2(2) unijna dyrektywa Rady 92/43/EEC, czyli tzw. dyrektywa siedliskowa. W Polsce, spośród ekosystemów leśnych, dotyczy to większości ekosystemów lasów liściastych (wszystkich buczyn, grądów, dąbrów i łęgów), ale także niżowych borów chrobotkowych, borów górskich, borów i lasów bagiennych oraz lasów na wydmach nadmorskich. Cel, jakim jest właściwy stan ochrony, rozumiany musi być w kontekście art. 2(1), który stanowi: „dyrektywa ma na celu przyczynienie się do zapewnienia różnorodności biologicznej poprzez ochronę siedlisk przyrodniczych (...)". Jednym z narzędzi wdrażania tego celu jest specjalna ochrona obszarów Natura 2000. Nic więc dziwnego, że we wszystkich krajach UE poszukuje się sposobów monitorowania siedlisk przyrodniczych, uwzględniających również ich funkcję podtrzymywania różnorodności biologicznej. Poszukuje się także odpowiednich rozwiązań planistycznych (sposobów określenia weryfikowalnych celów i środków jakie są potrzebne, by te cele osiągnąć). W przypadku ekosystemów leśnych, poszukiwania te uwzględniają między innymi kluczowe dla lasu elementy struktury ekosystemu, jakimi są różne formy rozkładającego się drewna i inne mikrosiedliska związane z drzewami. Praktycznie we wszystkich krajach UE udział drzew martwych, drzew starych, albo drzew ze specyficznymi mikrosiedliskami nadrzewnymi jest brany pod uwage przy ocenie stanu siedlisk przyrodniczych, choć różnie są ustalane szczegóły techniczne i wartości progowe. Planowanie ochrony często zaś stawia za cel poprawę ilości, jakości i zróżnicowania takich elementów strukturalnych (por. EUROPEAN UNION 2015).

Podejście takie jest oczywiste na obszarach chronionych. Jednak, także w lasach użytkowanych gospodarczo, celem gospodarki leśnej jest zwykle „użytkowanie zrównoważone”, tj. prowadzone tak, by trwale zachować ekosystem leśny i związaną z nim różnorodność biologiczną. Jeśli prowadzi się gospodarkę leśną w cyklu znacznie krótszym, niż naturalny czas życia drzew, to łatwo wyeliminować elementy ekosystemu związane ze starzeniem się drzew, do jakich należą drzewa biocenotyczne i rozkładające się drzewa większych rozmiarów. Próby integracji ochrony przyrody ze zrównoważoną gospodarką leśną (KRAUS \& KRUMm 2013) kładą więc nacisk na zapewnienie obecności takich drzew także w lasach „gospodarczych".

\section{MARTWE DRZEWA}

Literatura na temat roli martwych drzew w ekosystemie leśnym jest bogata, a liczba publikacji na ten temat szybko wzrasta. Oczywisty jest wpływ śmierci drzew i rozkładu ich pozostałości na zjawiska przepływu energii i obiegu materii w ekosystemie. Znany jest także wpływ na retencję wody, a ostatnio coraz częściej podkreślana jest rola 
w utrzymywaniu zasobów węgla (np. Coomes i in. 2002, Merganičová \& Merganič 2010; Merganičová i in. 2012; Paletto i in. 2014). Mniej oczywiste, ale równie ważne są np. oddziaływania na procesy odnawiania się innych drzew, modyfikacje mikrorzeźby terenu, wpływ na kształtowanie się runa leśnego, czy wymuszanie zmiany zachowania się zwierząt, a w ślad za tym - zmiany ich oddziaływania na ekosystemy. Z punktu widzenia ochrony przyrody kluczowe są związki między ilością i różnorodnością martwych drzew w ekosystemie a poszczególnymi aspektami różnorodności biologicznej. W praktycznych dyskusjach na temat ochrony przyrody padają najczęściej pytania: Ile martwego drewna powinno być w lesie? Jak powinno być zróżnicowane? Jak można to osiągnąć? Ekologia może co najwyżej odpowiedzieć, jakie ilości rozkładającego się drewna spotyka się w ekosystemach oraz czy istnieją i jakie są korelacje pomiędzy ilością i różnorodnością martwych drzew a mierzalnymi wskaźnikami różnorodności biologicznej lub funkcjonowaniem ekosystemu leśnego.

Najprostszym wskánikiem charakteryzującym zasoby martwych drzew w ekosystemie jest objętość rozkładającego się drewna na jednostce powierzchni. Cecha ta jest jednym ze wskaźników różnorodności biologicznej monitorowanych przez Europejską Agencję Środowiskową i badanych w ramach inwentaryzacji zasobów leśnych wielu krajów (KovAC i in. 2020). Dla zapewnienia porównywalności wyników przyjęto (EuROPEAN ENVIRONMENTAL AGENCY 2015), że bierze się pod uwagę leżące kłody i stojące pozostałości drzew, dłuższe niż $2 \mathrm{~m}$ i grubsze niż 7-10 cm (określenie progu minimalnej grubości pozostawiono poszczególnym państwom), nie bierze się natomiast pod uwagę drewna pniaków, korzeni, ani mniejszych fragmentów (co nie neguje ich ważnej roli ekologicznej). Zgromadzono w ten sposób wiele danych z różnych obiektów leśnych Europy. Średnia wartość wskaźnika w latach 2000-2010 wykazała wzrost od ok. 8 do ok. $10 \mathrm{~m}^{3} /$ ha, a raportowane przez EEA średnie dla poszczególnych krajów wg stanu na $2010 \mathrm{r}$. wynosiły od 3,9 $\mathrm{m}^{3} / \mathrm{ha}$ w Wielkiej Brytanii i 5,6 $\mathrm{m}^{3} / \mathrm{ha}$ w Polsce, po 26,2 $\mathrm{m}^{3} /$ ha na Słowacji, $21,3 \mathrm{~m}^{3} / \mathrm{ha}$ w Szwajcarii, $23 \mathrm{~m}^{3} / \mathrm{ha}$ na Litwie, $20,3 \mathrm{~m}^{3} / \mathrm{ha}$ w Austrii, $19 \mathrm{~m}^{3} / \mathrm{ha}$ w Słowenii, $17,7 \mathrm{~m}^{3} / \mathrm{ha}$ na Łotwie i $15 \mathrm{~m}^{3} / \mathrm{ha}$ w Niemczech. W Polsce takiego pomiaru dostarcza Wielkoobszarowa Inwentaryzacja Stanu Lasu (BIURo URZĄDZANIA LASU I GEODEZJI LeŚNEJ 2019), której dane wskazują, że zasoby w lasach Polski wzrosły z poziomu $5,8 \mathrm{~m}^{3} / \mathrm{ha}$ w 2010 r. do $8,0 \mathrm{~m}^{3} / \mathrm{ha}$ w $2018 \mathrm{r}$. (w tym w Lasach Państwowych odpowiednio z 5,2 $\mathrm{m}^{3} /$ ha do $7,5 \mathrm{~m}^{3} / \mathrm{ha}$; w parkach narodowych z $35,8 \mathrm{~m}^{3} / \mathrm{ha}$ do $45 \mathrm{~m}^{3} / \mathrm{ha}$ ). Stwierdzono równocześnie, że wartości te są bardzo silnie zróżnicowane geograficznie, np. w Lasach Państwowych w RDLP Zielona Góra, Toruń i Piła są mniejsze niż $4 \mathrm{~m}^{3} / \mathrm{ha}$, w RDLP Szczecinek, Szczecin i Warszawa mieszczą się w przedziale 4-5 $\mathrm{m}^{3} / \mathrm{ha}$, ale w RDLP Krosno przekraczają $23 \mathrm{~m}^{3} / \mathrm{ha}$.

Badania zasobów martwych drzew w konkretnych obszarach chronionej przyrody prowadzono w Europie wielokrotnie w różnej skali i typach lasu; w Polsce wiele publikacji w tym zakresie pojawiło się zwłaszcza w XXI w. (FIGARSKI i in. 2014; PAWLACZYK 2014; Zieliński \& PAWLACZyK 2016; Bujoczer \& BujoczeK 2016; Bujoczen i in. 2017a; MielCZARCZYK i in. 2018 i cytowana tam literatura). Wiele danych zebrano i zawarto także w niepublikowanych dokumentacjach do planów ochrony wykonanych w ostatnich latach. Objętość rozkładającego się drewna w europejskich lasach kształtowanych przez naturalne procesy może sięgać często do $100 \mathrm{~m}^{3} / \mathrm{ha}$, a punktowo nawet do $550 \mathrm{~m}^{3} / \mathrm{ha}$ (CHRISTENSEN 
i in. 2005). Dla chronionych od dłuższego czasu rezerwatów typowe są wartości rzędu kilkudziesięciu $\mathrm{m}^{3} / \mathrm{ha}$. Poziom ten jednak zwykle nie jest stabilny, często zasoby rozkładającego się drewna zmieniają się pulsacyjnie, odzwierciedlając zaburzenia w ekosystemie (np. zamieranie jodły, jesionu; wiatrowały) i regerenację po nich (por. MIELCZARCZYK i in. 2018).

Samo zagadnienie pomiaru ilości rozkładającego się drewna nie jest jednak proste metodycznie. Zazwyczaj stosuje się pomiar na systematycznie rozmieszczonych powierzchniach próbnych, zwykle kołowych. Takie podejście stosowane jest we wspomnianej wyżej Wielkoobszarowej Inwentaryzacji Stanu Lasu (WISL), a od 2011 r. najczęściej także w ramach prac inwentaryzacyjnych do planu urządzenia lasu (DYrekcJa Generalna Lasów PaŃSTWOWYCH 2012a). Można przy tym zliczać albo fragmenty rozkładającego się drewna leżące na powierzchni (takie jest podejście w WISL), albo fragmenty pochodzące z drzew rosnących na powierzchni (takie podejście przyjęto w urządzaniu lasu). Badania BuJoczKA (2015) sugerują, że to drugie podejście jest trudniejsze i bardziej pracochłonne, a daje mniej wiarygodne wyniki. Do pomiaru ilości drewna leżącego dobrze nadaje się też metoda linii siecznych, która jest jednak nieprzydatna do pomiaru martwych drzew stojących (FIGARSKI i in. 2014; Miścicki \& SOŁTYs 2019 i cytowana tam literatura). Poszukuje się też innych efektywnych metod (RITTER \& SABOROWSKI 2012).

Przy badaniu za pomoca próbkowania podstawowym problemem jest zwykle bardzo wysoki współczynnik zmienności i bardzo wysoka prawoskośność rozkładu ilości martwego drewna na powierzchniach próbnych (por. np. TRAVAGLiNI i in. 2007). Efekt ten można zniwelować zwiększając wielkość powierzchni, w przeciwnym razie dla uzyskania wiarygodnych wyników użyć trzeba dużej liczby powierzchni, co tak czy inaczej oznacza wysoką pracochłonność (por. BujoczeK i in. 2017b; Miścicki \& SOŁTYs 2019). Podejście przyjęte w urządzaniu lasu, zakładające pomiar martwego drewna na co dziesiątej kołowej powierzchni próbnej zakładanej do pomiaru drzewostanu, daje wynik o niskiej pewności, przydatny co najwyżej do obliczenia jednej wartości średniej dla nadleśnictwa (BUJOczEK i in. 2017b).

W wielu badaniach wykazano korelację między zasobnością martwych drzew ( $\left.\mathrm{w} \mathrm{m}^{3} / \mathrm{ha}\right)$ a różnorodnością biologiczną poszczególnych grup organizmów, a także występowaniem lub dobrym stanem populacji konkretnych gatunków. Korelacje te nie zawsze były silne (LASSAUCE $\mathrm{i}$ in. 2011), ponieważ związek różnorodności biologicznej z obecnością i ilością martwych drzew w lesie jest znacznie bardziej złożony. Równie ważna, a nawet ważniejsza niż sama ilość rozkładającego się drewna, może być jakość mikrosiedlisk z nim związanych, w tym obecność: grubych kłód, martwych drzew stojących, drzew w ściśle określonym stadium rozkładu, grubych fragmentów martwych drzew w miejscach ciepłych i naświetlonych (por. CZEREPKO i in. 2014; BAČE i in. 2019). Podkreśla się też, że ważniejsza od ilości martwego drewna może być ciągłość występowania poszczególnych jego postaci i rozmieszczenie w krajobrazie. Dla zachowania leśnej różnorodności biologicznej ważne jest by istniały także ostoje dla gatunków o bardzo wysokich wymaganiach co do zasobów martwego drewna i była zachowana między nimi łączność przestrzenna. Potrzebna jest sieć nieużytkowanych fragmentów lasu, niewystarczające jest natomiast osiągnięcie jakiegokolwiek średniego poziomu zasobów martwego drewna (RANIUS \& FAHRIG 2006). Złożoność przestrzennych i czasowych aspektów zagadnienia skłoniła SvERDRUP-THYGESON i in. 
(2014) do wniosku, że dotychczasowa wiedza wciąż nie upoważnia do wyciągania konkluzji co do ochrony gatunków zależnych od martwych drzew. Mimo to, inni autorzy wielokrotnie podejmowali próby zarysowania „wartości progowych” ilości rozkładającego się drewna niezbędnych dla zachowania poszczególnych elementów różnorodności biologicznej (PAWLACZYK 2015 i cytowana tam literatura). Dla lasów Europy fundamentalne znaczenie ma podsumowująca wyniki takich prac metaanaliza MÜLLER i BÜTLER (2010), sugerująca, że takie wartości progowe kształtują się w Europie na poziomie $10-80 \mathrm{~m}^{3} / \mathrm{ha}$,

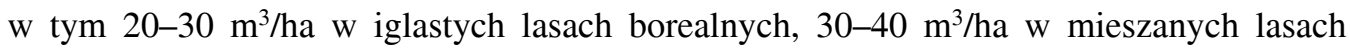
górskich oraz $30-50 \mathrm{~m}^{3} / \mathrm{ha}$ w liściastych lasach niżowych. Wyniki te wykorzystano w rekomendacjach praktycznych (KraUs \& KRUMM 2013; EUROPEAN UNION 2015).

\section{MiKROSIEDLISKA NADRZEWNE}

Co najmniej od XIX w. ekolodzy i leśnicy świadomi są znaczenia, jakie dla różnych składników przyrody mają takie elementy związane z drzewami, jak dziuple i wykroty. Świadomość ta poszerzała się stopniowo o dostrzeganie roli innych struktur - martwych konarów żywych drzew, obłamań konarów, hub i owocników innych grzybów nadrzewnych, pęknięć pni drzew i specyficznych struktur korowiny, wertykalnych kobierców mszystych na pniach itp. W ekologii ekosystemów leśnych nurt badań nad występowaniem i znaczeniem takich struktur przybrał na sile od pierwszych lat XXI w. (WINTER i in. 2005; WiNTER \& MÖLLER 2008); wtedy też na ich określenie pojawił się termin „mikrosiedliska nadrzewne” (tree microhabitas). Wypracowano katalogi i typologię takich mikrosiedlisk (KRAUS i in. 2016; LARRIEU i in. 2018). Ocena zagęszczenia takich struktur (lub drzew z mikrosiedliskami, określanych często jako habitat trees - drzewa biocenotyczne) została zaproponowana jako wskaźnik zróżnicowania strukturalnego lasu i potencjalny predyktor leśnej różnorodności biologicznej.

Związki pomiędzy ilością i różnorodnością mikrosiedlisk nadrzewnych a stanem poszczególnych grup organizmów w ekosystemie leśnym potwierdzono w wielu badaniach (np. LARRIEU i in. 2018; PAILlET i in. 2018), choć często okazują się one skomplikowane i nie mają charakteru prostych korelacji.

$\mathrm{Z}$ drugiej strony, wiele badań poświęcono próbom ustalenia, jak kształtują się i od czego zależą zasoby mikrosiedlisk w poszczególnych ekosystemach (np. VUIDOT i in. 2011; LARRieu \& CABanetTes 2012; LaRrieu i in. 2012, 2014; PAILet i in. 2017; KozÁK i in. 2018; AsBECK i in. 2019). W poszczególnych pracach wykazywano korelacje zasobów mikrosiedlisk z wieloma czynnikami, jak skład gatunkowy drzewostanu i jego różnorodność, historia użytkowania lub biernej ochrony drzewostanu. Niemal zawsze bardzo silny był jednak związek rozmiarów (a tym samym wieku) drzew z bogactwem wykształcających się na nich mikrosiedlisk. Dopiero na drzewach starszych niż 100-120 lat i grubszych niż 70-100 cm miało szansę wykształcić się pełne zróżnicowanie takich struktur, a szczególne znaczenie miały drzewa 150-200 letnie.

Metodą badania mikrosiedlisk nadrzewnych jest zwykle ich rejestracja i zliczanie na powierzchniach próbnych. Szczegóły badań nasuwają jednak trudności wynikające z samego zróżnicowania takich struktur. Bardzo silny jest wpływ przyjętego katalogu 
mikrosiedlisk i szczegółowego sposobu ich interpretacji. Znaczny jest także efekt obserwatora, związany z jego doświadczeniem $\mathrm{w}$ ich wyszukiwaniu, a także wpływ fenologii w związku z rozwojem ulistnienia drzew. Bezpośrednio porównywalne są więc raczej wyniki badań przeprowadzonych przez ten sam zespół i tą samą metodą w różnych obiektach, a nie wyniki uzyskane w rozmaitych okolicznościach przez różnych badaczy.

Niewiele na razie jest przykładów polskich badań nad mikrosiedliskami nadrzewnymi. Jednym z nich jest analiza wykonana w ramach prac nad oceną stanu siedlisk przyrodniczych w obszarze Natura 2000 Uroczyska Puszczy Drawskiej PLH320046, oparta na pomiarach na systematycznej siatce 118 powierzchni kołowych o wielkości 0,05 ha (PAWLACZYK 2014) metodą WINTER i MÖLLER (2008). Zagęszczenie mikrosiedlisk w leśnych siedliskach przyrodniczych użytkowanych jako lasy gospodarcze okazało się dwukrotnie mniejsze, niż w Drawieńskim Parku Narodowym, utworzonym 23 lata wcześniej (w 1990 r.) z gospodarczych drzewostanów. Nawet w Parku było ono jednak znacznie mniejsze niż w buczynach niemieckich badanych przez WINTER i MöLLER (2008), choć ten akurat wynik mógł być skutkiem niedokładnego odwzorowania metodyki. Wyraźnie zaznaczał się jednak deficyt tych typów mikrosiedlisk, których powstawanie trwa stosunkowo długo, np. próchnowisk. Występowanie mikrosiedlisk było w zasadzie ograniczone do drzew w wieku $>100$ lat, przy czym zauważono wyraźny, dość zresztą oczywisty, pozytywny związek liczby mikrosiedlisk z wiekiem drzew. Podobne badania w mniejszej skali przestrzennej, porównujące chroniony od 1991 r. rezerwat przyrody Łubówko z sąsiednimi starodrzewami dębowymi w lasach gospodarczych nadleśnictwa Smolarz w Puszczy Drawskiej, przeprowadzili ZIELIŃSKI i PAWLACZYK (2016) przy pomocy metodyki GIOŚ (PAWLACZYK 2015, zob. niżej). Tu także zagęszczenie mikrosiedlisk jak i drzew z mikrosiedliskami w rezerwacie okazało się trzykrotnie wyższe niż w starych drzewostanach gospodarczych.

Warto zaznaczyć, że w polskiej tradycji leśnej od dawna istnieje pojęcie „drzew biocenotycznych"; jest ono obecnie wyrażone w Instrukcji Ochrony Lasu (DYREKCJA GENERALNA Lasów PaŃstwowych 2012b). Do drzew biocenotycznych według tej instrukcji zalicza się w szczególności drzewa z wypróchnieniami, z hubami, z ranami pnia, z uszkodzeniami od pioruna, złamane, z koroną częściowo (powyżej 1/3) obumarłą, z dziuplami lub próchnowiskami (także powstałymi w miejscach zranień po obumarłych gałęziach); są to więc m.in. drzewa z mikrosiedliskami nadrzewnymi. Jak dotąd jednak nie podejmowano prób ilościowej analizy występowania takich drzew w ekosystemie leśnym, ani ich dynamiki.

\section{OCENA STANU SIEDLISK PRZYRODNICZYCH}

W związku z wdrażaniem w Unii Europejskiej wymogów dyrektywy siedliskowej i zestandaryzowanych wymagań raportowania, we wszystkich państwach UE wypracowano krajowe metody oceny stanu siedlisk przyrodniczych, oparte na jednolitym zestawie parametrów (powierzchnia siedliska, jego struktura i funkcja oraz perspektywy ochrony), ale w poszczególnych krajach różniące się pod względem kryteriów oceny struktury ekosystemu. Zrozumienie znaczenia przyrodniczego martwych drzew i „drzew biocenotycznych” sprawiło jednak, że nie ma kraju, który w stosunku do leśnych siedlisk przyrodniczych nie 
wykorzystywałby w jakiś sposób wskaźników odnoszących się do ich obecności i ilości (CZEREPKO i in. 2014).

O ile sama idea jest wspólna, to sposób jej praktycznej realizacji jest różny. Mimo badania podobnych wskaźników (KovAC i in. 2020), stosowane są bardzo rozmaite kryteria oceny ilości i jakości martwego drewna (por. THAURONT \& STALLEGGER 2008; TABOR 2014). Przykładowo, w Brandenburgii jako próg właściwego stanu siedlisk przyrodniczych Natura 2000 przyjęto objętość martwego drewna $40 \mathrm{~m}^{3} / \mathrm{ha}$. ZINGSTRA i in. (2009) w bułgarskim przewodniku do oceny stanu siedlisk przyrodniczych przyjęli, że „we właściwym stanie leśnego siedliska przyrodniczego martwe drewno powinno stanowić powyżej $8 \%$ miąższości drzewostanu i równocześnie powinno być co najmniej 10 martwych drzew stojących na hektar". Dla naturalnych lasów borealnych oraz olsów w krajach bałtyckich zalecono utrzymanie objętości martwych drzew powyżej $50 \mathrm{~m}^{3} / \mathrm{ha}$, a dla renaturyzowanych lasów gospodarczych - dążenie do co najmniej 20-30 m³/ha, przy zachowaniu pełnego zróżnicowania faz rozkładu (KURIS \& RUSKULE 2006). Jednak wiele innych państw przyjęło kryteria znacznie mniej ambitne, a wręcz zupełnie pozbawione ambicji - na poziomie $\mathrm{kilku} \mathrm{m}^{3} / \mathrm{ha}$ lub 1-3 większych martwych drzew na hektar. Może to mieć złe konsekwencje dla skuteczności ochrony (por. dalej).

W Polsce krajowy monitoring i ocena stanu ochrony siedlisk przyrodniczych jest częścią Państwowego Monitoringu Środowiska. Polega on na powtarzalnych obserwacjach na stanowiskach założonych według subiektywnego wyboru ekspertów, który miał jednak uwzględniać zróżnicowanie stanu zachowania ekosystemów w poszczególnych obszarach Natura 2000. Metodyka oceny stanowiska dla większości leśnych siedlisk przyrodniczych polega na wykonaniu obserwacji i pomiarów wzdłuż transektu $200 \times 20$ m, w ramach którego zlicza się także zasoby rozkładającego się drewna (GENERALNY INSPEKTORAT OCHRONY ŚRODOWISKA 2015). Wskaźnik ten z nieznanych przyczyn pominięto w metodyce monitorowania borów bagiennych. Kryteria oceny stanu leśnych siedlisk przyrodniczych (za wyjątkiem borów chrobotkowych i świetlistych dąbrów), stosowane do poszczególnych płatów siedliska, zakładają dla większości leśnych siedlisk przyrodniczych próg „stanu właściwego" pod względem zasobów martwego drewna na poziomie $20 \mathrm{~m}^{3} /$ ha, wymagając równocześnie więcej niż pięciu fragmentów wielkowymiarowego rozkładającego się drewna (ponad 3 m długości i ponad $50 \mathrm{~cm}$ średnicy; z tym że w lasach gdzie drzewa nie dorastają do takich grubości bierze się pod uwagę fragmenty o średnicy ponad $30 \mathrm{~cm}$ ). Odpowiednio, wartości $10 \mathrm{~m}^{3} /$ ha i trzy sztuki są wartościami granicznymi między oceną niezadowalającą a złą. Stan siedliska w większym obszarze można uznać za właściwy, gdy powyższe kryterium stanu właściwego spełniają płaty reprezentujące co najmniej 1/4 powierzchni siedliska. W porównaniu z innymi państwami Europy są to progi dość ambitne, ale wciąż jeszcze dalekie od zalecanych np. w sąsiedniej Brandenburgii. Przyjęte w Polsce kryteria wydają się dość trafne, z jednej strony w świetle wiedzy o wymaganiach ekologicznych gatunków związanych z martwym drewnem, a z drugiej strony w świetle stanu polskich lasów. Przykładowo, dla żyznych buczyn badanych w latach 2015-2018 (LEWCZUK 2019), na $36 \%$ stanowisk ogólne zasoby martwego drewna oceniono jako właściwe, na $26 \%$ jako niezadowalające, a na 38\% jako złe - co wydaje się dość trafnie odzwierciedlać przyrodniczą kondycję tych lasów na obszarach Natura 2000. Nieco gorszy okazał się ich stan 
pod względem wielkowymiarowych fragmentów rozkładającego się drewna (32\% stanowisk w stanie właściwym, $16 \% \mathrm{w}$ niezadowalającym, 52\% w złym). Według ostatnio opublikowanych analiz Bujoczka i in. (2020) opartych na danych z Wielkoobszarowej Inwentaryzacji Stanu Lasu, średnia ilość rozkładającego się drewna w leśnych siedliskach przyrodniczych na obszarach Natura 2000 w Polsce wynosi $12,7 \mathrm{~m}^{3} / \mathrm{ha}$, w tym np. w borach górnoreglowych - 55,4 $\mathrm{m}^{3} / \mathrm{ha}$, w żyznych buczynach $-28,7 \mathrm{~m}^{3} / \mathrm{ha}$, w łęgach jesionowo-olszowych $-25,1 \mathrm{~m}^{3} / \mathrm{ha}$, w grądach subatlantyckich $-21,5 \mathrm{~m}^{3} / \mathrm{ha}$, w grądach środkowoeuropejskich - 9,3 $\mathrm{m}^{3} /$ ha, Natomiast średnia liczba wielkowymiarowych fragmentów zmienia się się od zera w świetlistych dąbrowach i borach chrobotkowych i 2,7 szt/ha w kwaśnych dąbrowach do 16,3 szt/ha w żyznych buczynach i 31,1 szt/ha w borach górnoreglowych.

Jak dotąd, ilościowych miar występowania mikrosiedlisk nadrzewnych nie wprowadzono w Europie na szerszą skalę do oceny stanu siedlisk przyrodniczych, mimo że wydaje się pod tym kątem obiecująca. Popularne jest wprawdzie liczenie „drzew biocenotycznych”, ale kryteria, na podstawie których dane drzewo jest do nich zaliczone, często nie są jasne. W Polsce w 2015 r. wprowadzono do praktyki, jako element monitoringu kilku typów siedlisk przyrodniczych, ilościową ocenę mikrosiedlisk nadrzewnych i drzew, na których one występują. Podejście to zostało opisane w metodyce dla siedliska przyrodniczego żyznych buczyn (PAWLACZYK 2015), a odwołując się do tego opisu, wprowadzono je także jako element monitoringu kwaśnych buczyn, grądów subkontynentalnych i olsów. Jest ono wzorowane na metodzie WINTER i MöLLER (2008), choć uproszczono ją tak, by można ją zastosować w szybkiej, a masowej ocenie stanu ochrony siedlisk przyrodniczych. Na wyznaczanym do oceny różnych wskaźników transekcie $200 \times 20$ m rejestruje się występowanie drzew: $\mathrm{z}$ hubami, z obłamaniami korony, z zamarłymi głównymi konarami w koronie, złamanych z rozszczepieniem na wiele drzazg, z bliznami piorunowymi, z pęknięciami pnia, z dziuplami, z próchnowiskami, a także wykrotów. Osobno liczy się drzewa o prawdopodobnym wieku wyższym niż 150 lat, co nie jest równoznaczne z występowaniem mikrosiedlisk nadrzewnych, ale wyraża potencjał do ich powstawania. Zliczeniu podlegają zarówno mikrosiedliska jak i drzewa z mikrosiedliskami, przy czym wyskalowanie oceny stanu wskaźnika oparto na tej drugiej wartości (por. niżej).

Ocenę wyskalowano wstępnie, przyjmując 20 lub więcej drzew z mikrosiedliskami na hektar lasu jako próg stanu właściwego, a 10 drzew/ha jako próg , poniżej którego stan uznaje sie za zły. Równocześnie zastrzeżono, że wskaźnik ten wymaga dalszej kalibracji, bowiem dostępne dane były bardzo skape. Założenia okazały się jednak dość trafne. Dla żyznych buczyn badanych w latach 2015-2018 (LEWCZUK 2019) na 36\% stanowisk liczbę drzew z mikrosiedliskami oceniono jako właściwą, na 33\% jako niezadowalającą, a na $31 \%$ jako złą, co wydaje się dobrze odpowiadać przyrodniczej kondycji tych lasów.

Drzewa z mikrosiedliskami, przy założeniu powyższej metody, mogą być uznane za „drzewa biocenotyczne” w sensie Instrukcji Ochrony Lasu (por. wyżej), choć wymaga to odpowiedniej interpretacji tej instrukcji: wykroty zaliczyć trzeba do „drzew martwych”; drzewa stare z reguły będą „wyróżniające się wiekiem lub rozmiarami”, pęknięcia i blizny piorunowe to „otwarte rany pnia”, a obłamana korony to ,pozbawienie korony na skutek złamania”. Nie każde „drzewo biocenotyczne” w sensie Instrukcji będzie natomiast „drzewem z mikrosiedliskami” w sensie metodyki GIOŚ. 
W metodykach monitoringu siedlisk przyrodniczych opracowanych i opublikowanych w latach 2010-2012 (dotyczących m.in. łęgów, kwaśnych dąbrów i grądów subatlantyckich), wskaźnik dotyczący martwego drewna determinował ocenę parametru „struktury i funkcji siedliska przyrodniczego", który nie mógł być oceniony wyżej niż ocena tego wskaźnika. W metodykach opracowanych po 2015 r. (tj. dotyczących żyznych i kwaśnych buczyn, grądów subkontynentalnych i olsów) zliberalizowano to podejście. Zachowano jednak zasadę, że spośród trzech wskaźników drzewnych (ogólne zasoby martwego drewna, martwe drewno wielkowymiarowe, mikrosiedliska nadrzewne), choć jeden musi być w stanie właściwym, by móc ocenić syntetyczny stan siedliska przyrodniczego jako właściwy.

Celem krajowego monitoringu siedlisk przyrodniczych jest śledzenie zmian, jakim podlegać będą wybrane płaty siedlisk. Ponieważ stanowiska monitoringowe wybrane zostały subiektywnie, nie stanowią próby o cechach losowości. Zebrane na nich dane ilościowe o zasobach martwego drewna i mikrosiedlisk nadrzewnych nie mogą więc być wykorzystane do obliczenia średnich wartości dla areału danego siedliska w Polsce. Podobnie, w skali pojedynczego obszaru Natura 2000 liczba stanowisk krajowego monitoringu jest zwykle za mała, by dobrze charakteryzować ten obszar. Jeżeli zależy nam na poznaniu liczbowych charakterystyk tych cech siedlisk przyrodniczych w obszarze Natura 2000, konieczne jest systematyczne ich zbadanie, np. na siatce powierzchni próbnych, przykładowo tak jak zrobiono to w ramach prac nad planem zadań ochronnych obszaru Uroczyska Puszczy Drawskiej PLH320046 (PAWLACZYK 2014).

\section{KONSEKWENCJE DLA OCHRONY SIEDLISK PRZYRODNICZYCH}

Zrozumienie znaczenia martwych drzew i mikrosiedlisk nadrzewnych dla funkcjonowania ekosystemów leśnych i związanej z nimi różnorodności biologicznej przekłada się na cele ochrony stawiane w procesie planowania obszarów chronionych. Szczególnie silnie odzwierciedla się to w procesie planowania ochrony obszarów Natura 2000, gdy punkt odniesienia stanowi właściwy stan ochrony siedlisk przyrodniczych określony mierzalnymi wskaźnikami.

Zbyt niskie wskaźniki stanu ochrony stosowane w niektórych krajach mogą rzutować na nieskuteczność planowanej ochrony. WINTER i in. (2014) zwracają uwagę, że w takich sytuacjach deklaratywne osiągnięcie ,właściwego stanu ochrony” nie będzie wcale oznaczało zachowania lub odtworzenia różnorodności biologicznej typowej dla leśnych siedlisk przyrodniczych. Niektóre analizy (ZEHETMAIR i in. 2015a, b) zdają się potwierdzać tę tezę o słabości i bezskuteczności obszarów Natura 2000 w dziedzinie „ochrony bioróżnorodności poprzez ochronę siedlisk przyrodniczych”. Ta sytuacja wymaga więc naprawy.

W Polsce prawo przesądza, że w planowaniu ochrony obszarów Natura 2000 „do oceny struktury i funkcji siedliska przyrodniczego stosuje się, możliwe do zastosowania na danym obszarze Natura 2000, zestawy wskaźników przyjęte na podstawie wiedzy naukowej do celów państwowego monitoringu przyrodniczego". Oznacza to, że powinny być w nich uwzględnione zasoby rozkładającego się drewna w leśnych siedliskach przyrodniczych, a także mikrosiedliska nadrzewne (przynajmniej w buczynach i w grądach 
subkontynentalnych). Do rzadkości należą jednak przypadki, w których aktualny stan tych elementów w obszarze jest rzetelnie ustalany. Zwykle poprzestaje się na opisaniu kilku stanowisk siedliska przyrodniczego, podczas gdy określenie zasobów martwego drewna i mikrosiedlisk nadrzewnych wymagałoby raczej pomiarów i obserwacji na regularnej, dość gęstej siatce powierzchni próbnych, albo zastosowania innych metod o podobnej intensywności (por. wyżej). Mimo to, cel sformułowany jako „poprawa wskaźników dotyczących martwego drewna" dość często pojawia się wśród celów działań ochronnych.

Pozostaje jednak pytanie, jakie środki powinny być zastosowane, by ten cel osiągnąć (por. BAuHus i in. 2009). Standardowym podejściem jest ,pozostawianie pojedynczych drzew biocenotycznych, w tym martwych, jeżeli nie stwarza to zagrożenia dla drzewostanu", co generalnie jest realizowane w lasach i zalecane także przez Instrukcję Ochrony Lasu (Dyrekcja Generalna Lasów Państwowych 2012b). Środek taki może jednak okazać się niewystarczający. Wiele badań sugeruje, że podstawowym czynnikiem decydującym o powstawaniu mikrosiedlisk nadrzewnych jest starzenie się drzew i osiąganie przez nie określonego wieku i rozmiarów. LARRIEU i CABANETTES (2012), REGNERY i in. (2013) oraz LARRIEU i in. (2014) rekomendują troskę nie tylko o istniejące już mikrosiedliska, ale także o drzewa, na których w najbliższym czasie mogłyby się one rozwinąć, w tym pozostawianie drzew powyżej określonych progów wymiarowych (od 65 do $100 \mathrm{~cm}$ pierśnicy zależnie od gatunku). Aby mogły pojawić się mikrosiedliska nadrzewne, drzewa muszą mieć szansę się zestarzeć.

Podobnie, za utrzymujący się deficyt martwego drewna najprawdopodobniej nie odpowiada usuwanie pojedynczych drzew martwych, a raczej usuwanie drzew zamierających; uprzątanie „szkód” po lokalnych zaburzeniach, np. wiatrołomach, a przede wszystkim sposób gospodarki sprawiający, że drzewa są wycinane zanim osiaggną starość. Kluczem do zmiany tej sytuacji są takie rozwiązania, które przynajmniej niektórym drzewom dają szansę osiagnnięcia naprawdę dojrzałego wieku (por. LARRIEU i in. 2014; ASBECK i in. 2019; BAČE i in. 2019).

W tej sytuacji właściwe środki ochronne służące odbudowie rozważanych struktur w ekosystemach leśnych powinny polegać na:

- wydzieleniu sieci obszarów leśnych, przeznaczonych wyłącznie do ochrony przyrody, nie mniejszych niż kilkadziesiąt hektarów (rolę tę spełniać powinny rezerwaty przyrody);

- pozostawianiu bez użytkowania fragmentów lasu o wielkości rzędu kilku hektarów; w tym pozostawianie ich także na obszarach zniszczonych przez huragany, masowe zamieranie drzew itp.;

- konsekwentnym pozostawianiu przy cięciach rębnych kilkuarowych „biogrup” starego drzewostanu, także przy rębniach złożonych w lasach liściastych; z założeniem, że tak pozostawione drzewa wejdą w skład nowego drzewostanu, będą w nim miały szanse się zestarzeć, wytworzyć mikrosiedliska i w końcu stać się martwym drewnem wielkowymiarowym;

- bardzo konsekwentnym pozostawianiu drzew biocenotycznych, w tym także całych grup drzew uszkodzonych przez wiatr lub inne czynniki.

Według badań BANASIA i in. (2014) w lasach obszarów Natura 2000 jest wprawdzie znacząco więcej martwego drewna niż w lasach poza tymi obszarami, ale nie jest to wynik 
ochrony, a raczej wyznaczenia obszarów Natura 2000 tam, gdzie elementy przyrodnicze były w lepszym stanie. Jeśli poważnie traktować cel ,przyczynienie się do zapewnienia różnorodności biologicznej poprzez ochronę siedlisk przyrodniczych", to potrzebny jest jednak wzrost zasobów martwego drewna. By go uzyskać, trzeba przynajmniej niektórym drzewom pozwolić się zestarzeć, zamrzeć z przyczyn naturalnych i pozostawić je do naturalnego rozkładu. Ten sam postulat stosuje się także do odbudowy zasobów mikrosiedlisk nadrzewnych.

Osiągnięcie poprawy zasobów martwych drzew i drzew biocenotycznych w polskich lasach, choć słuszne i pożądane z ekologicznego punktu widzenia, musiałoby nieuchronnie oznaczać pewne ograniczenie ilości pozyskiwanego drewna. Ważnym zagadnieniem pozostaje, jak poważnym obciążeniem byłoby to dla gospodarki leśnej i jej ekonomiki. Zagadnienie to jest dość złożone. Zmiana zasobów martwego drewna to proces dynamiczny, a nie prosta akumulacja. Analiza musi więc uwzględniać także ubytek zasobów wskutek naturalnego rozkładu. Pozostawianie starych drzew na gruncie wiąże się z nieosiągnięciem przychodu ze sprzedaży ich drewna, ale wpływa także na koszty gospodarki leśnej - przy czym przypuszczać można, że ogranicza koszty w przypadku pozostawiania bez ingerencji większych powierzchni, ale może wręcz zwiększać koszty w przypadku pozostawiania pojedynczo rozproszonych drzew. Próby analizy ekonomicznych konsekwencji dążenia do zwiększenia zasobów martwych drzew w lasach gospodarczych podejmowali np. HoleKSA i in. (2014) oraz HëRTL i KNOKE (2019). Uzyskane wyniki wskazują, że problem ten nie jest banalny. Z drugiej strony, wzrasta wciąż wiedza pokazująca, jak ważna jest rola pełniona w ekosystemie leśnym przez martwe drzewa i przez różnorodność biologiczną związaną z mikrosiedliskami nadrzewnymi. Koszty związane z odtworzeniem tych elementów w lasach, zubożonych przez poprzednie pokolenie leśników, zapewne warto więc ponieść. Obecna struktura wiekowa polskich lasów wydaje się sprzyjać podjęciu takiego wyzwania. Prognoza ZajĄCZKOwSKIEGo i Neroja (2019) pokazuje, że nawet W scenariuszu zmniejszenia - z powodów ochrony przyrody - intensywności użytkowania rębnego i przedrębnego lasów w Polsce odpowiednio o $15 \%$ i 10\%, możliwości pozyskania drewna w skali kraju nie spadną, a wzrosną od 34,6 mln $\mathrm{m}^{3} \mathrm{w}$ latach 2018-2020 do około 45,9 mln $\mathrm{m}^{3}$ grubizny netto w latach 2046-2050. Być może właśnie teraz jest więc właściwy moment na zwiększenie wysiłków na rzecz odtworzenia strukturalnego, i w konsekwencji przyrodniczego bogactwa polskich lasów, do czego drzewa stare, biocenotyczne i martwe mogą się przysłużyć.

Podziękowania. Artykuł został przygotowany w ramach działalności statutowej Klubu Przyrodników.

\section{LITERATURA}

Asbeck T., Pyttel P., Frey J. \& Bauhus J. 2019. Predicting abundance and diversity of tree-related microhabitats in Central European montane forests from common forest attributes. - Forest Ecology and Management 432: 400-408.

BaČe R., Svoboda M. \& VítKová L. 2019. Deadwood management in production forests. Management guidelines for forest managers in Central European temperate forests. s. 31. Department of Forest Ecology, Faculty of Forestry and Wood Sciences, Czech University of Life, Praha. 
Banaś J., BujoczeK L., ZięBA S. \& Drozd M. 2014. The effects of different types of management, functions, and characteristics of stands in Polish forests on the amount of coarse woody debris. - European Journal of Forest Research 133: 1095-1107.

Bauhus J., Puettmann K. \& Messier Ch. 2009. Silviculture for old-growth attributes. - Forest Ecology and Management 258: 525-537.

BiURo URZĄZZANiA LASU i GeOdEZJI LeŚNEJ. 2019. Wielkoobszarowa inwentaryzacja stanu lasów w Polsce. Wyniki za okres 2014-2018. s. 557. Biuro Urządzania Lasu i Geodezji Leśnej, Sękocin Stary.

BujoczeK L. 2015. Problematyka pomiarów oraz określania miąższości martwego drewna na kołowych powierzchniach próbnych. - Sylwan 159(10): 795-803.

BujoczeK L. \& BujoczeK M. 2016. Zasoby oraz zróżnicowanie martwego drewna w uroczysku Wapienny Las w Nadleśnictwie Polanów. - Sylwan 160(6): 482-491.

Bujoczer L., ZięBA S. \& BujoczeK M. 2020. Variation in deadwood microsites in areas designated under the habitats directive (Natura 2000). - Forests 11: 486: doi:10.3390/f11050486.

Bujoczek L., BARANiewicz E., BANAŚ J. \& ZięBA S. 2017a. Martwe drewno w buczynach objętych ochroną ścisłą uroczyska „Rozsypaniec” w Bieszczadzkim Parku Narodowym. - Roczniki Bieszczadzkie 25: 267-278.

Bujoczek L., BujoczeK M., BAnaś J. \& ZięBA S. 2017b. Inwentaryzacja martwego drewna statystyczną metodą reprezentacyjną z zastosowaniem warstw gatunkowo-wiekowych. - Sylwan 161(2): 114-123.

Christensen M., Hahn K., Mountford E. P., Odor P., Standovar T., Rozenbergar D., Diaci J., WijDeVen S., Meyer P., Winter S. \& VRska T. 2005. Dead wood in European beech (Fagus sylvatica) forest reserves. - Forest Ecology and Management 210: 267-282.

Coomes D. A., Allen R. B., Scott N. A., Goulding C. \& Beets P. 2002. Designing systems to monitor carbon stocks in forests and shrublands. - Forest Ecology and Management 164(1-3): 89-108.

CZERePKo J., HiLsZCZAŃski J. \& JABŁoŃSki M. 2014. Martwe drewno - żywy problem. - Studia i Materiały Centrum Edukacji Przyrodniczo-Leśnej w Rogowie 41(4): 36-45.

DyreKcja Generalna Lasów Państwowych. 2012a. Instrukcja urządzania lasu. Załącznik do Zarządzenia nr 55 Dyrektora Generalnego Lasów Państwowych z dnia 21 listopada 2011 r. s. 287. Centrum Informacyjne Lasów Państwowych, Warszawa.

Dyrekcja Generalna Lasów Państwowych. 2012b. Instrukcja ochrony lasu. Załącznik do Zarządzenia nr 57 Dyrektora Generalnego Lasów Państwowych z dnia 22 listopada 2011 r. s. 124. Centrum Informacyjne Lasów Państwowych, Warszawa.

EuRoPeAn ENVIRonmental AgEnCy. 2015. Forest: deadwood. Indicator Specification, Indicator codes: SEBI 018. https://www.eea.europa.eu/data-and-maps/indicators/forest-deadwood-1 (dostęp: 15.01.2020).

EUROPEAN UnION. 2015. Natura 2000 and forests. s. $113+62$. Office for Official Publications of the European Communities, Luxembourg.

FigARSKI T., BuChHOLz L. \& SzCZYGIELSKI M. 2014. Struktura zasobów drewna martwych drzew w Świętokrzyskim Parku Narodowym i jego znaczenie dla zachowania populacji wybranych gatunków chrząszczy saproksylobiontycznych. - Studia i Materiały Centrum Edukacji Przyrodniczo-Leśnej w Rogowie 41(4): 258-272.

GENERALNY InSPEKTORAT OCHRONY ŚRODOWISKA. 2015. Monitoring gatunków i siedlisk przyrodniczych. Przewodniki metodyczne. http://siedliska.gios.gov.pl/pl/publikacje/przewodniki-metodyczne (dostęp: 14.01.2020).

Gutowski J. M. (red.), Bobiec A., Pawlaczyk P. \& Zub K. 2004. Drugie życie drzewa. s. 245. WWF Polska, Fundacja Ekonomistów Środowiska i Zasobów Naturalnych, Warszawa - Hajnówka. 
HÄRTL F. \& KNOKE T. 2019. Coarse woody debris management with ambiguous chance constrained robust optimization. - Forests 10(6): 504, doi: 10.3390/f10060504.

HoleKsA J., ŻywIEC M. \& KUREK P. 2014. Ilość obumarłych drzew w lasach gospodarczych w związku z wymaganiami ochrony przyrody na obszarach Natura 2000 - od statycznego do dynamicznego podejścia. - Studia i Materiały Centrum Edukacji Przyrodniczo-Leśnej w Rogowie 41(4): 15-29.

Kovac M., Gasparini P., Notarangelo M., Rizzo M., Cañellas I., Fernández-de-Uña L. \& Alberdi I. 2020. Towards a set of national forest inventory indicators to be used for assessing the conservation status of the Habitats Directive forest habitat types. - Journal for Nature Conservation 53: 125747, https://doi.org/10.1016/j.jnc.2019.125747.

Kozák D. M., Mikoláš M., Svitok M., Bače R., Paillet Y., Larrieu L., Nagel T. A., Begovič K., Čada V., Diku A., Frankovič M., Janda P., Kameniar O., Keren S., Kuučukov P., Lábusová J., Langbehn T., Málek J., Mikac S., Morrissey R. C., Novákova M., Schurrman J. S., Svobodová K., Synek M., Teodosiu M., Toromani E., Trotsiuk V., Vítková L. \& Svoboda M. 2018. Profile of tree-related microhabitats in European primary beech-dominated forests. - Forest Ecology and Management 429: 363-374.

Kraus D. \& KRUMm F. (red.). 2013. Integrative approaches as an opportunity for the conservation of forest biodiversity. s. 284. European Forest Institute, Freiburg.

Kraus D., Bütler R., Krumm F., Lachat T., Larrieu L., Mergner U., Paillet Y., Rydkvist T., SCHUCK A. \& WINTER S. 2016. Catalogue of tree microhabitats - Reference field list. s. 16. "Integrate+ Technical Paper". Regional Office EFICENT, European Forest Institute, Freiburg. https://informar.eu/ sites/default/files/pdf/Catalogue_Tree-Microhabitats_Reference-Field-List_EN.pdf

KURIS M. \& RUSKULE A. 2006. Favourable conservation status of boreal forests: monitoring, assessment, management. s. 44. Baltic Environmental Forum, Tallin.

LARRIEU L. \& CABANETtES A. 2012. Species, live status, and diameter are important tree features for diversity and abundance of tree microhabitats in subnatural montane beech-fir forests. - Canadian Journal of Forest Research 42(8): 1433-1445.

Larrieu L., Cabanettes A. \& Delarue A. 2012. Impact of silviculture on dead wood and on the distribution and frequency of tree microhabitats in montane beech-fir forests of the Pyrenees. - European Journal of Forest Research 131: 773-786.

Larrieu L. \& Cabanettes A., Brin A., Bouget Ch. \& Deconchat M. 2014. Tree microhabitats at the stand scale in montane beech-fir forests: practical information for taxa conservation in forestry. - European Journal Forest Research 133(2): 355-367.

Larrieu L., Cabanettes A., Gonin P., Lachat T., Paillet Y., Winter S., Bouget C. \& Deconchat M. 2014. Deadwood and tree microhabitat dynamics in unharvested temperate mountain mixed forests: A life-cycle approach to biodiversity monitoring. - Forest Ecology and Management 334: 163-173.

Larrieu L., Paillet Y., Winter S., Bütler R., Kraus D., Krummg F., Lachat T., Micheli A., RegNERY B. \& VANDEKERKHOVE K. 2018. Tree related microhabitats in temperate and Mediterranean European forests: A hierarchical typology for inventory standardization. - Ecological Indicators 84: 194-207.

Lassauce A., Paillet Y., Jactel H. \& Bouget Ch. 2011. Deadwood as a surrogate for forest biodiversity: Meta-analysis of correlations between deadwood volume and species richness of saproxylic organisms. - Ecological Indicators 11(5): 1027-1039.

LEwCZUK M. 2019. Sprawozdanie z monitoringu siedliska 9130 żyzne buczyny. s. 148. Główny Inspektorat Ochrony Środowiska, Warszawa.

LindenMayer D. B., Franklin J. F. \& Fischer J. 2006. General management principles and a checklist of strategies to guide forest biodiversity conservation. - Biological Conservation 131(3): 433-445. 
Merganičová K. \& Merganič J. 2010. Coarse woody debris carbon stocks in natural spruce forests of Babia hora. - Journal of Forest Science 56(9): 397-405.

Merganičová K., Merganič J., Svoboda M., BaČE R. \& ŠEbeň V. 2012. Deadwood in forest ecosystems. - W: J. A. Blanco \& Y.-H. Lo (red.), Forest Ecosystems - More than Just Trees. IntechOpen. https:// www.intechopen.com/books/forest-ecosystems-more-than-just-trees/deadwood.

MielcZARCZYK J., Miścicki S. \& LePA A. 2018. Dynamika zasobów martwych drzew w ścisłym rezerwacie przyrody Świnia Góra. - Sylwan 162(4): 295-304.

MiścicKi S. \& SoŁTYS A. 2019. Liczba i wielkość jednostek próbnych do pomiaru leżących martwych drzew metodą liniową. - Sylwan 163(1): 35-46.

MÜLLER J \& BÜTLER R. 2010. A review of habitat thresholds for dead wood: a baseline for management recommendations in European forests. - European Journal of Forest Research 129: 981-992.

Paillet Y., Archaux F., Boulanger V., Debaive N., Fuhr M., Gilg O., Gosselin F. \& Guilbert E. 2017. Snags and large trees drive higher tree microhabitat densities in strict forest reserves. - Forest Ecology and Management 389: 176-186.

Paillet Y, Archaux F, du Puy S., Bouget Ch., Boulanger V., Debaive N., Gilg O., Gosselin F. \& GUILBERT E. 2018. The indicator side of tree microhabitats: A multi-taxon approach based on bats, birds and saproxylic beetles. - Journal of Applied Ecology 55: 2147-2159.

Paletto A., De Meo I., Cantiani P. \& Ferretti F. 2014. Effects of forest management on the amount of deadwood in Mediterranean oak ecosystems. - Annals of Forest Science 71: 791-800.

PAWLACZYK P. 2014. Martwe drewno i mikrosiedliska nadrzewne w leśnych siedliskach przyrodniczych Puszczy Drawskiej. - Studia i Materiały Centrum Edukacji Przyrodniczo-Leśnej w Rogowie 41(4): 86-97.

PAWLACZYK P. 2015. 9130 Żyzne buczyny. - W: W. Mróz (red.), Monitoring siedlisk przyrodniczych. Przewodnik metodyczny. Część IV, s. 249-272. Główny Inspektorat Ochrony Środowiska, Warszawa.

PAWLACZYK P. 2016. Martwe drzewa w ochronie żywej przyrody. - W: A. WiKŁo (red.), Stan ekosystemów leśnych Puszczy Białowieskiej. Ogólnopolska Konferencja Naukowa Ministerstwa Środowiska i Generalnej Dyrekcji Lasów Państwowych 28.10.2015, Warszawa, s. 59-86. Centrum Informacyjne Lasów Państwowych, Warszawa.

RANIUS T. \& FAHRIG L. 2006. Targets for maintenance of dead wood for biodiversity conservation based on extinction thresholds. - Scandinavian Journal of Forest Research 21: 201-208.

Regnery B., Paillet Y., Couvet D. \& Kerbiriou Ch. 2013. Which factors influence the occurrence and density of tree microhabitats in Mediterranean oak forests? - Forest Ecology and Management 295: $118-125$.

RITTER T. \& SABOROwSKI J. 2012. Point transect sampling of deadwood: a comparison with well-established sampling techniques for the estimation of volume and carbon storage in managed forests. - European Journal of Forest Research 131: 1845-1856.

Stokland J. N., Sirtonen J. \& Jonsson B. G. 2012. Biodiversity in dead wood. s. 509. Cambridge University Press, Cambridge.

Sverdrup-Thygeson A., Gustafsson L. \& Kouki J. 2014. Spatial and temporal scales relevant for conservation of dead-wood associated species: Current status and perspectives. - Biodiversity and Conservation 23(3): 513-535.

TABOR J. 2014. Kryteria oceny zasobów martwego drewna w Polsce i w Europie. - Studia i Materiały Centrum Edukacji Przyrodniczo-Leśnej w Rogowie 41(4): 46-60.

Thauront M. \& Stallegger M. 2008. Management of Natura 2000 habitats. 9110 Luzulo-Fagetum beech forests. European Commission, s. 26. - European Commission Technical Report 2008 22/24. 
Travaglini D., Barbati A., Chirici G., Lombardi F., Marchetti M. \& Corona P. 2007. ForestBiOTA data on deadwood monitoring in Europe. - Plant Biosystems - An International Journal Dealing with all Aspects of Plant Biology 141(2): 222-230.

Vuidot A., Paillet Y, Archaux F. \& Gosselin F. 2011. Influence of tree characteristics and forest management on tree microhabitats. - Biological Conservation 144(1): 441-450.

WinTER S. \& MöLLER G. C. 2008. Microhabitats in lowland beech forests as monitoring tool for nature conservation. - Forest Ecology and Management 255(3-4): 1251-1261.

Winter S., Flade M., Schumacher H., Kerstan E. \& Möller G. 2005. The importance of near-natural stand structures for the biocoenosis of lowland beech forests. - Forest Snow and Landscape Research 79(1-2): 127-144.

Winter S., Borrass L., Geitzenauer M., Blondet M., Breibeck R., Weiss G. \& Winkel G. 2014. The impact of Natura 2000 on forest management: a socio-ecological analysis in the continental region of the European Union. - Biodiversity Conservation 23: 3451-3482.

ZająCZKowski S. \& Neroj B. 2019. Prognoza rozwoju zasobów drzewnych w lasach polskich oraz potencjalne możliwości ich użytkowania. Materiały 119 Zjazdu Polskiego Towarzystwa Leśnego „Wielofunkcyjna gospodarka leśna wobec oczekiwań przemysłu drzewnego i ochrony przyrody", 12.09.2019, Darłówko. http://ptl.pl/posts/konferencje-naukowe (dostęp: 18.02.2020).

Zehetmair T., Müller J., Zharov A. \& GrupPe A. 2015a. Effects of Natura 2000 and habitat variables used for habitat assessment on beetle assemblages in European beech forests. - Insect Conservation and Diversity 8(3): 193-204.

Zehetmair T., Müller J., Runkel V., Stahlschmidt P., Winter S., Zharov A. \& Gruppe A. 2015 b. Poor effectiveness of Natura 2000 beech forests in protecting forest-dwelling bats. - Journal for Nature Conservation 23: 53-60.

ZIELIŃSKi S. \& PAWLACZYK P. 2016. Rezerwat Jezioro Łubówko w Puszczy Drawskiej po 25 latach ochrony: martwe drewno, mikrosiedliska nadrzewne i przyczynek do poznania fauny chrząszczy saproksylicznych. - Przegląd Przyrodniczy 27(4): 82-97.

Zingstra H., KovaČev A., Kitnaes K., Conev R., Dimova D. \& CvetKov P. 2009. R"kovodstvo za ocenka na blagopriyatno prirodozashtitno s"stoânie za tipove prirodni mestoobitaniâ i vidove po NATURA 2000 v B"lgariâ. s. 630. Izd. B"lgarska Fondaciâ Bioraznoobrazie, Sofiâ.

\section{SUMMARY}

Decaying wood is of key importance to forest ecosystem dynamics and biodiversity. Today there is growing appreciation of the role of tree-related structural elements such as holes, cavities, trunk and crown breakage, cracks and scars, bark pockets, dead branches and polypores. The objective of modern nature conservation, in particular the Habitat Directive of the European Union, is to maintain and conserve biodiversity through conservation of natural habitats. Maintaining and restoring deadwood and tree habitat resources is an essential part of nature conservation.

The literature on deadwood and coarse woody debris in forests is extensive. The amount of deadwood in a forest is one of the Streamlined European Biodiversity Indicators monitored by the European Environmental Agency as part of sustainable development monitoring. The European average for its increase in 2000-2010 was $8-10 \mathrm{~m}^{3} / \mathrm{ha}$, ranging from $3.9 \mathrm{~m}^{3} / \mathrm{ha}$ in the UK and $5.6 \mathrm{~m}^{3} / \mathrm{ha}$ in Poland to $26.2 \mathrm{~m}^{3} / \mathrm{ha}$ in Slovakia. More accurate data from Poland show an increase from $5.8 \mathrm{~m}^{3} / \mathrm{ha}$ in 2010 to $8.0 \mathrm{~m}^{3} / \mathrm{ha}$ in 2018, geographically ranging from less than $4 \mathrm{~m}^{3} / \mathrm{ha}$ in the Zielona Góra, Torun and Piła Forest Directorates to $23 \mathrm{~m}^{3} / \mathrm{ha}$ in the Krosno Forest Directorate. Many studies confirm a correlation between deadwood amount and biodiversity, but the issue is in fact much more complicated. The quality and specific features of deadwood may be more important than quantity, and the spatial and temporal scales may be significant 
to its role. A fundamental metanalysis by MÜLLER \& BÜTLER (2010) suggests deadwood thresholds for biodiversity at $20-30 \mathrm{~m}^{3} / \mathrm{ha}$ for boreal coniferous forests, $30-40 \mathrm{~m}^{3} / \mathrm{ha}$ for mixed montane forests, and $30-50 \mathrm{~m}^{3} / \mathrm{ha}$ for lowland oak-beech. Measurement of deadwood resources faces specific problems and requires a well-considered methodology.

Tree microhabitats may be just as important as deadwood. Typologies and catalogues of microhabitats are available (KRAUS et al. 2016; LARRIEU et al. 2018). Microhabitats are not as well researched as deadwood, but the dependence of biodiversity on microhabitats is rather well confirmed. Numerous studies attempt to predict microhabitats and diversity using forest features; the strong dependence of microhabitats on tree dimensions and age has been shown. Polish forestry uses the term "biocenotic trees" (habitat trees), covering all trees with microhabitats. Works on tree microhabitats are rare; papers by PAWLACZYK (2014) and ZIELIŃSKI \& PAWLACZYK (2016) are exceptions.

All European Union countries use some deadwood and/or habitat tree indicators in assessing the conservation status of natural habitats, but the thresholds used by particular countries vary. Some of them are ambitious: $40 \mathrm{~m}^{3} / \mathrm{ha}$ in Brandenburg, Germany, $50 \mathrm{~m}^{3} / \mathrm{ha}$ in the Baltic region, $8 \%$ of stand volume in Bulgaria. In other countries the thresholds are below desirable levels, for example $3-5 \mathrm{~m}^{3} / \mathrm{ha}$; this often leads to inappropriate conservation planning. In Poland the threshold for a favourable conservation status for most forest natural habitats has been established at $20 \mathrm{~m}^{3} / \mathrm{ha}$. A specific feature of Polish monitoring is a quantitative approach to tree microhabitats, with a threshold of 20 hosting trees per ha.

Understanding of the significance of deadwood and tree habitats is usually followed by integration of these structures in management planning for protected areas, including Natura 2000 sites. If the assessment thresholds are not ambitious enough, the conservation measures will not be appropriate. In such cases, Natura 2000 will not serve as an effective tool for habitat-related biodiversity conservation. In better cases, objectives aimed at increasing deadwood resources are often formulated. The relevant conservation measures should not be limited to leaving single pieces of deadwood or habitat trees, but should also include various forms of tree retention. Giving trees a chance to grow old is one important measure. The opportunities created by local disturbances also should be used to increase deadwood and tree microhabitats.

Wptynęto: 15.01.2020 r.; przyjęto do druku: 24.02.2020 r. 